\title{
The Labyrinth Behind an Acute Respiratory Failure
}

\author{
Mirela Tiglis ${ }^{1,2}$, Tudor Hurmuzache', Cristina Bologa', Ioana Cristina Grintescu, ${ }^{1,2}$, Tiberiu Paul Neagu ${ }^{3,4}$, \\ Cezar Pavelescu ${ }^{5}$, Camelia Cristina Diaconu ${ }^{6,7}$, Ovidiu Gabriel Bratu ${ }^{8,9}$, Gabriel Constantinescu ${ }^{7,10}$, \\ Bogdan Socea ${ }^{11,12}$, Ioana Marina Grintescu ${ }^{1,2}$
}

\begin{abstract}
Introduction: Acute hypoxemic respiratory failure may have different causes. Case presentation: We present the case of a 42-year-old woman, with history of recent thyroidectomy and a late history of sleeve gastrectomy, who presented for acute dyspnoea. The chest X-ray revealed hydropneumothorax, and, therefore, an intercostals chest tube drainage was inserted. The evolution was unfavourable, with further respiratory status deterioration. A computed tomography of the thorax and abdomen was performed, that revealed a dilated thoracic oesophagus and stenosis of the esophagogastric junction, with lack of substance in the oesophageal wall and extravasation of oesophageal content in the posterior mediastinum, due to an oesophageal pleural fistula. An oesophageal stent was inserted under endoscopic guidance and the patient underwent minim-invasive surgical interventions for evacuation of the mediastinal and pleural collections, with a favourable evolution. Conclusions: Acute respiratory failure can be the face of multiple conditions, some of these can be life threatening and in need for rapid detection and treatment.
\end{abstract}

Keywords: acute respiratory failure, sleeve gastrectomy, oesophageal pleural fistula, oesophageal stent, chest tube, mediastinitis

\section{Rezumat}

Introducere: Insuficiența respiratorie acută hipoxemică poate avea ca substrat numeroase cauze. Prezentare de caz: Vă prezentăm cazul unei paciente de 42 de ani, cu istoric recent de tiroidectomie și sleeve gastric realizat în urmă cu aproximativ 11 ani, care se prezintă la spital pentru un episod de dispnee acută. Se efectuează radiografie pulmonară decelându-se hidropneumotorace, motiv pentru se montează drenaj pleural activ de urgență. Evoluția este însă nefavorabilă, cu deteriorarea progresivă a statusului respirator. Se impune efectuarea unei examinări computer tomograf de torace și abdomen și se evidențiază un esofag toracic dilatat, asociat cu o stenoză de

\footnotetext{
${ }^{1}$ Department of Anesthesiology and Intensive Care, Emergency Clinical Hospital of Bucharest, Bucharest, Romania

${ }^{2}$ Clinic of Orthopaedics and Trauma, Clinical Emergency Hospital, Bucharest, Romania

${ }^{3}$ Department of Plastic Surgery and Reconstructive Microsurgery, Emergency Clinical Hospital of Bucharest, Romania

${ }^{4}$ Clinical Department No. 11, „Carol Davila" University of Medicine and Pharmacy, Bucharest, Romania

${ }^{5}$ Emergency Clinical Hospital of Bucharest, Department of Thoracic Surgery, 8 Floreasca Avenue, 014461, Bucharest, Romania

${ }^{6}$ Department of Internal Medicine, Emergency Clinical Hospital of Bucharest, Romania

${ }^{7}$ Clinical Department No. 5, „Carol Davila" University of Medicine and Pharmacy, Bucharest, Romania
}

${ }^{8}$ Department of Urology, „Dr. Carol Davila" Central Military Emergency University Hospital, Bucharest, Romania

${ }^{9}$ Clinical Department No. 3, „Carol Davila” University of Medicine and Pharmacy, Bucharest, Romania

${ }^{10}$ Department of Gastroenterology, Emergency Clinical Hospital of Bucharest, Romania

${ }^{11}$ Clinical Department No. 10, „Carol Davila" University of Medicine and Pharmacy Bucharest, Bucharest, Romania ${ }^{12}$ Department of General Surgery, „St. Pantelimon" Emergency Clinical Hospital, Bucharest, Romania

\section{Corresponding author.}

Tiberiu Paul Neagu, Department of Plastic Surgery and Reconstructive Microsurgery, Emergency Clinical Hospital, $8^{\text {th }}$ Floreasca Avenue, $1^{\text {st }}$ District, Bucharest, Romania. E-mail: dr.neagupaul@gmail.com 
joncțiune eso-gastrică și lipsă de substanță la nivelul peretelui esofagian, cu extravazarea substanței de contrast în mediastinul posterior, secundar unei fistule eso-pleurale. Sub ghidaj endoscopic, se montează un stent metalic expandabil la nivel esofagian și pacienta este supusă unor intervenții chirurgicale minim invazive pentru evacuarea colecțiilor purulente mediastinale și pleurale, cu evoluție favorabilă. Concluzii: Insuficiența respiratorie acută poate fi manifestarea principală a multor patologii, unele dintre acestea chiar amenințătoare de viață, impunându-se un diagnostic și un tratament de urgență.

Cuvinte cheie: insuficiență respiratorie acută, sleeve gastric, fistulă pleuro-esofagiană, stent esofagian, pleurostomă, mediastinită

\section{INTRODUCTION}

Acute respiratory failure is an emergency that can raise problems of differential diagnosis. It can be determined by pneumonia, pulmonary oedema, acute respiratory distress syndrome (ARDS), chronic obstructive pulmonary disease, restrictive lung disorders, diaphragmatic disorders, brain injury, septic shock etc, but rarely is caused by digestive-pulmonary fistula and other diseases ${ }^{1}$. Gastro-pleural fistulas are uncommon and they appear usually secondary to pulmonary or digestive surgery, Boerhaave Syndrome, malignancy, tuberculosis, trauma, caustic ingestion, infection, mechanical ventilation or an instrumentation and, in the last years, after bariatric surgery ${ }^{2}$. Sakran N. et al reported a $0.2 \%$ risk of fistula appearance after sleeve gastrectomy ${ }^{3}$. Spontaneous cases were rarely found ${ }^{4}$. The mortality rate in these patients is very high, oesophageal pleural fistula being a life-threatening condition ${ }^{5}$. Clinical manifestations are nonspecific and patients usually present with fever, cough, chest pain, haemoptysis, wheezing or dyspnoea ${ }^{6}$. There are numerous paraclinical investigations used for the diagnosis of gastro-pleural fistula: computed tomography (CT), endoscopy, bronchoscopy and contrast swallow studies ${ }^{7}$. The therapeutic management includes pharmacological treatment of the

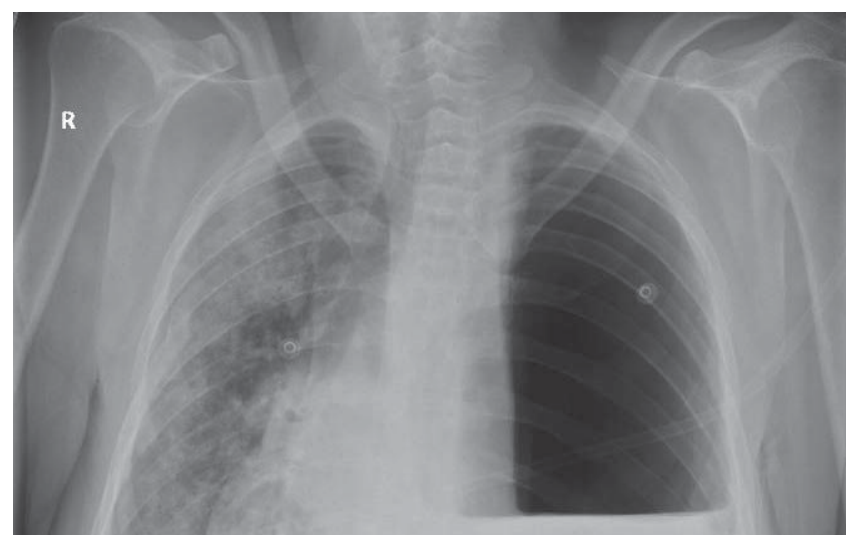

Figure 1. Chest X-ray - Left Hydropneumothorax. complications, endoscopic interventions (oesophageal /gastric stent) ${ }^{3}$, bronchoscopic intervention (tracheal or bronchial stent) or surgery for correcting the defects or the complications (soft tissue interposition flaps or 2-layer technique to close the oesophagus, partial resection, neo-oesophagus, pleural drainage, mediastinal drainage, etc.) ${ }^{8}$.

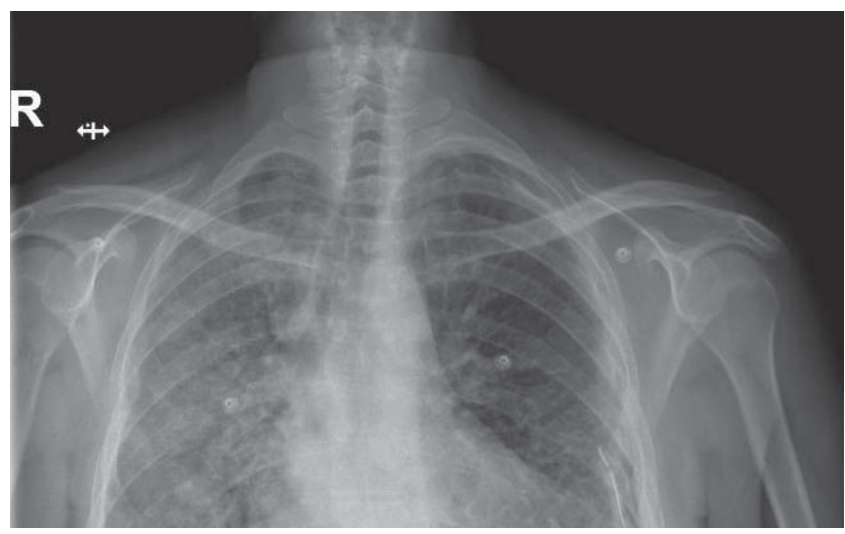

Figure 2. Chest X-ray - Left pleural drainge tube.

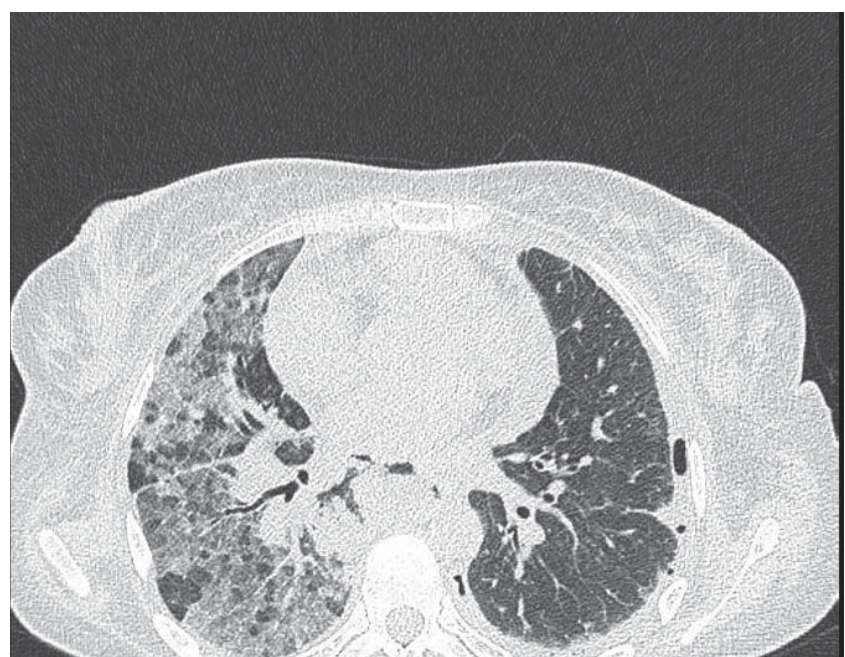

Figure 3. Computed tomography - bilateral brochopneumonia, pericarditis, mediastinal and paraoesophageal collections. 


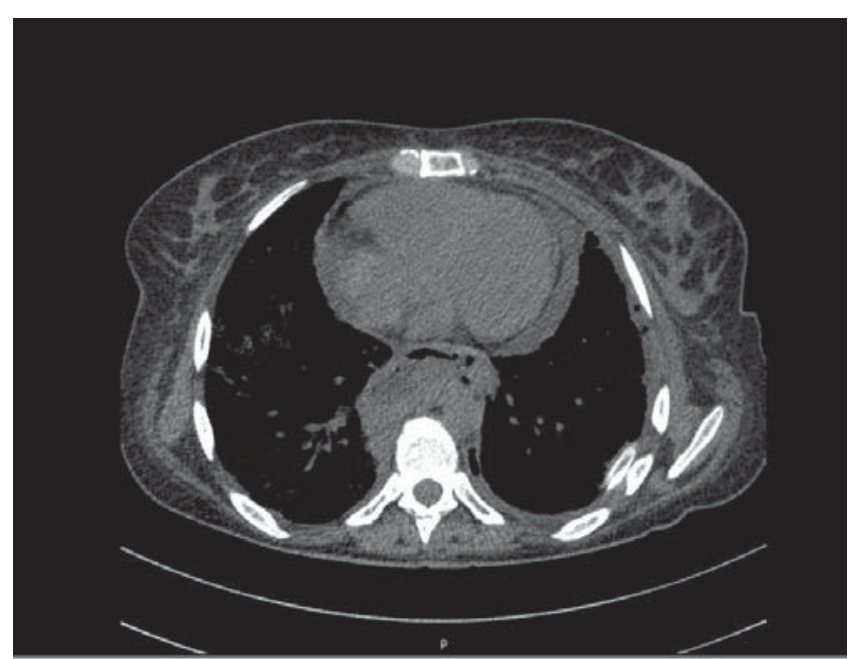

Figure 4. Computed tomography - lack of substance in the anterior oesophageal wall and extravasation of oesophageal content in the posterior mediastinum.

\section{CASE REPORT}

A 42-year-old woman was referred to our hospital for acute hypoxemic respiratory failure, apparently a week after total thyroidectomy. She also had a history of sleeve gastrectomy 11 years before, with no significant complication, and anxiety-depressive disorder. The arterial blood gases analysis showed severe hypoxemia with lactacidemia. A chest X-ray was performed in the emergency department, revealing a massive left hydropneumothorax (Figure 1). The thoracic surgeon inserted a left intercostals chest tube drainage, with consecutive evacuation of a very large amount of purulent liquid (which was sent for microbiological culture), but

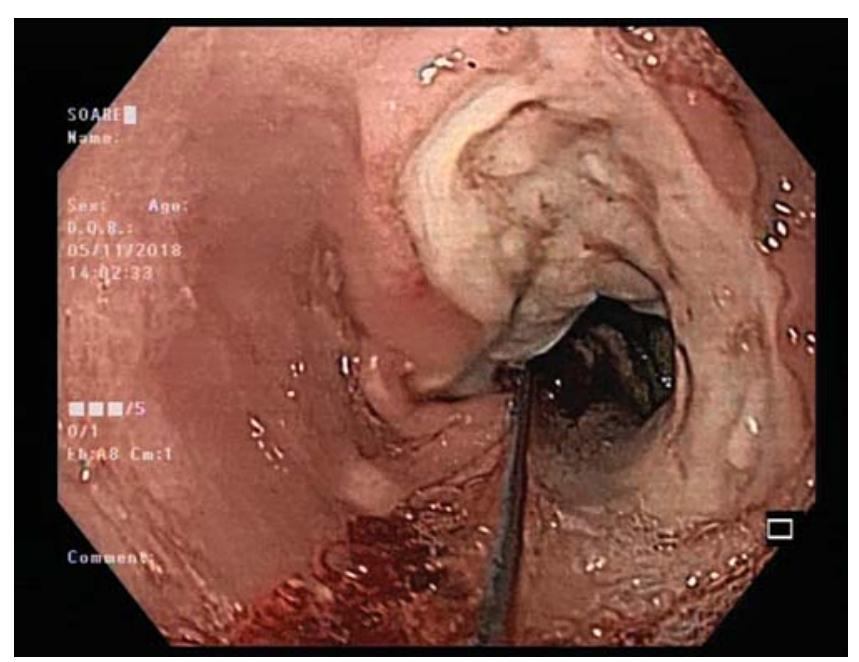

Figure 5. Upper endoscopy - superior oesophagus stenosis.

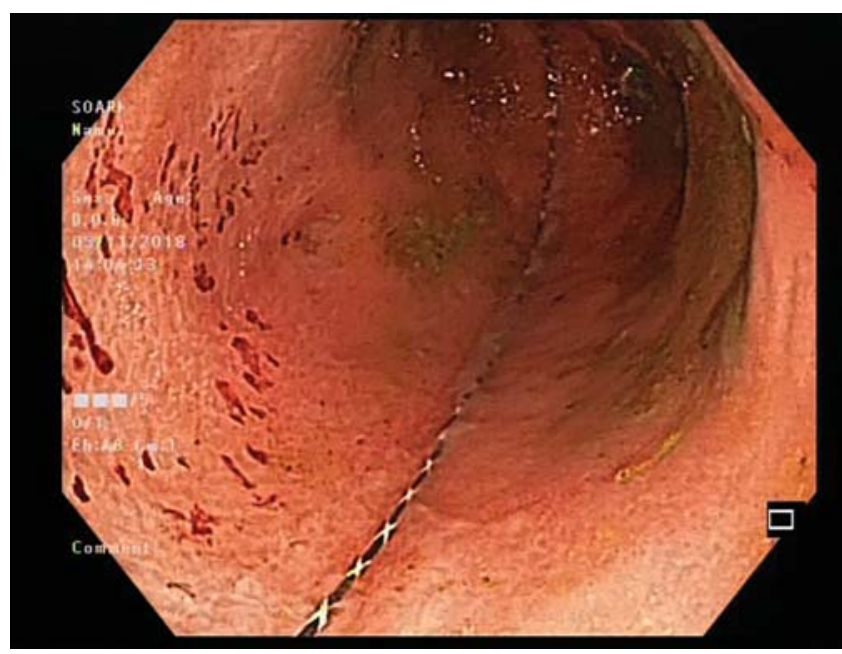

Figure 6. Upper endoscopy - guidance wire.

the respiratory status continued to deteriorate (Figure 2). Therefore, a computed tomography of the thorax and abdomen was performed, that revealed a dilated thoracic oesophagus and stenosis of the esophagogastric junction, with lack of substance in the anterior oesophageal wall and extravasation of oesophageal content in the posterior mediastinum, due to a bilateral oesophageal pleural fistula, periesophageal fluids collections, right interstitial and alveolar pneumonia, bilateral pleural effusion and pericarditis (Figure 3 and Figure 4). Consequently, the patient was admitted into intensive care unit (ICU) for sepsis with mediastinitis and right pneumonia as starting point, due to bilateral oesophageal pleural fistulas. Laboratory tests have

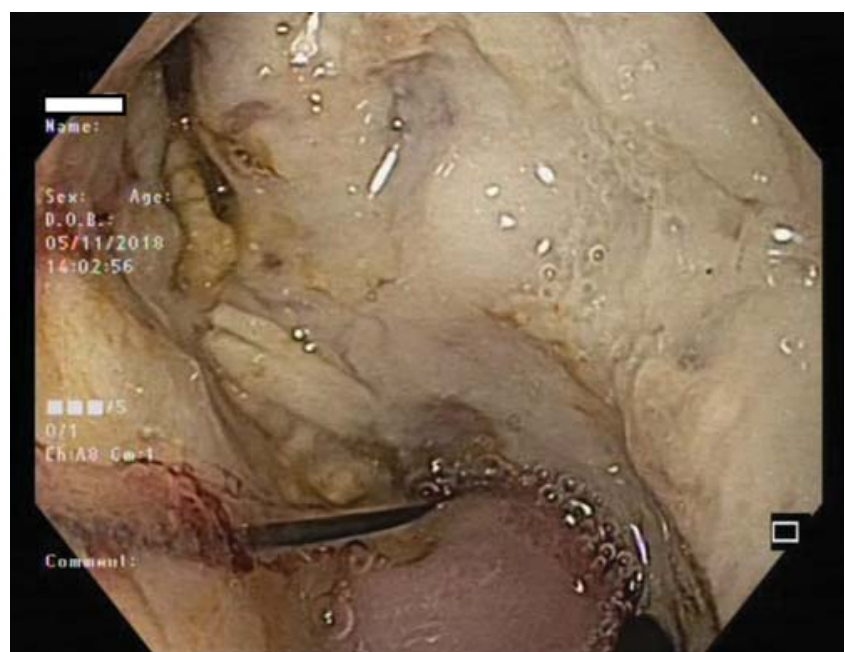

Figure 7. Upper endoscopy - necrotic appearance of the oesophageal mucosa. 


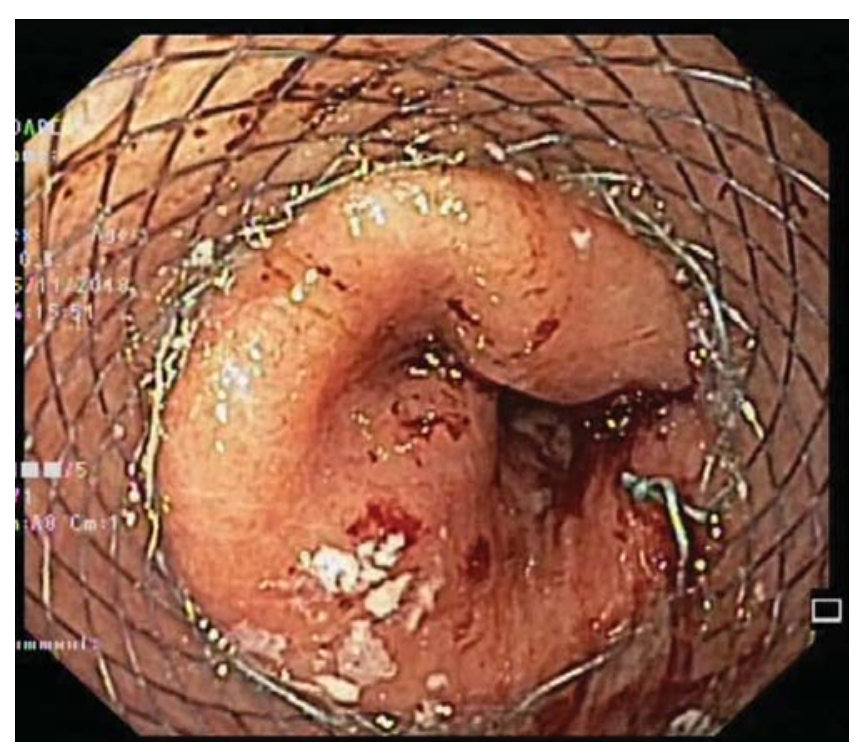

Figure 8. Upper endoscopy - oesophageal stent.

shown severe leukocytosis, moderate anaemia, hypoxemia and hyperlactatemia.

The gastroenterologist performed an upper endoscopy, revealing superior oesophagus stenosis. Using a GIF-HQ165 gastroscope, a guidance wire was advanced downstream of stenosis and successive dilatations were made with bougies (Figure 5 and Figure 6). Below this stenosis, the oesophageal mucosa had a necrotic appearance, with a mucosal defect of $5 \mathrm{~cm}$ at this level (Figure 7). In the light of these findings, with $a G I F$ HQ190 gastroscope, a guidance wire was advanced to the stomach level and a fully covered self-expandable metal stent was placed, to cover the oesophageal muco-

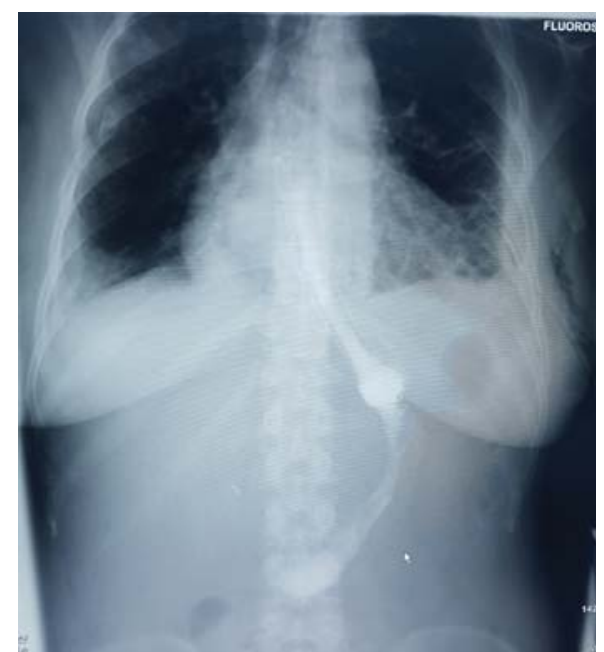

Figure 9. Gastropraphy - lack of extravasation of the contrast substance.

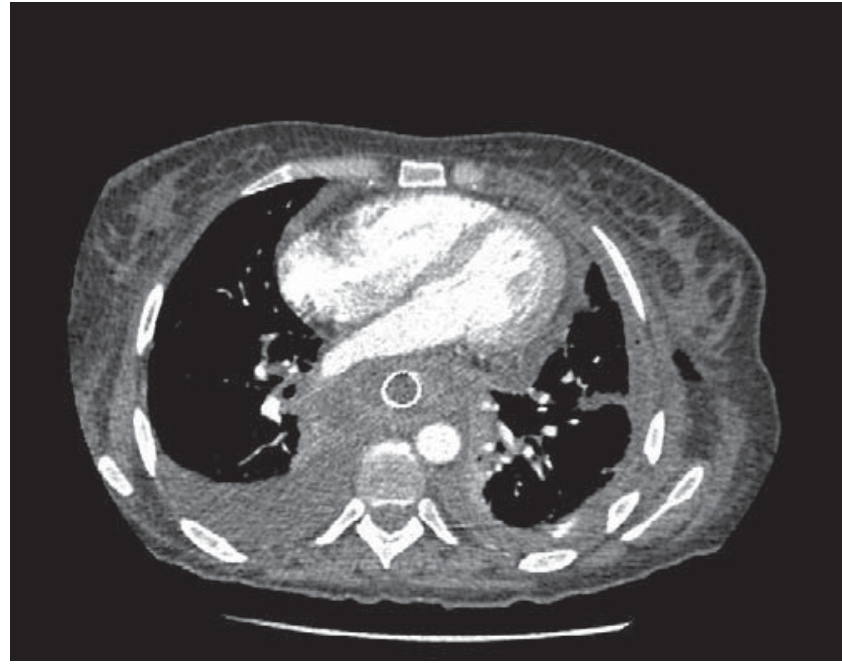

Figure 10. Computed tomography - paraoesophageal and mediastinal collections.

sal defect (Figure 8). In the meantime, the antibiotherapy was adjusted accordingly to the cultures' results from pleural liquid. The respiratory status improved, with hypoxemia' correction, but the patient is still in need for oxygen therapy. A gastrography procedure was performed, in order to test the stent functionality, and the patient started eating on its own (Figure 9). Hypoxemia developed again and oxygen therapy with high-flow heated humidification have been used, but the respiratory dysfunction persisted. A flexible bronchoscopy was performed at bedside, with secondary bronchoaspiration due to a left lobe atelectasis, leading to subsequent correction of hypoxemia. In the $7^{\text {th }}$ day

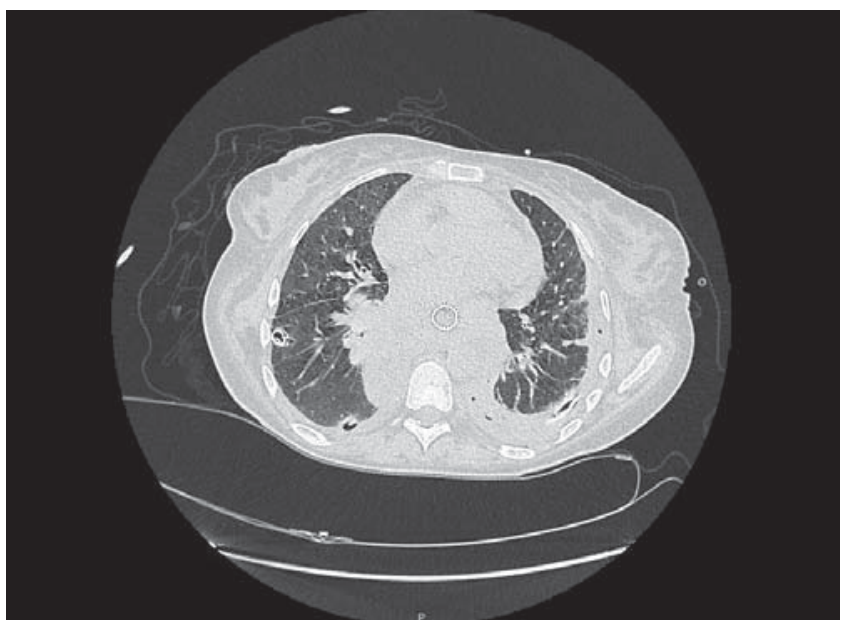

Figure 11. Computed tomography - oesophageal stent, right pleural effusion, interlobular septal thickening. 


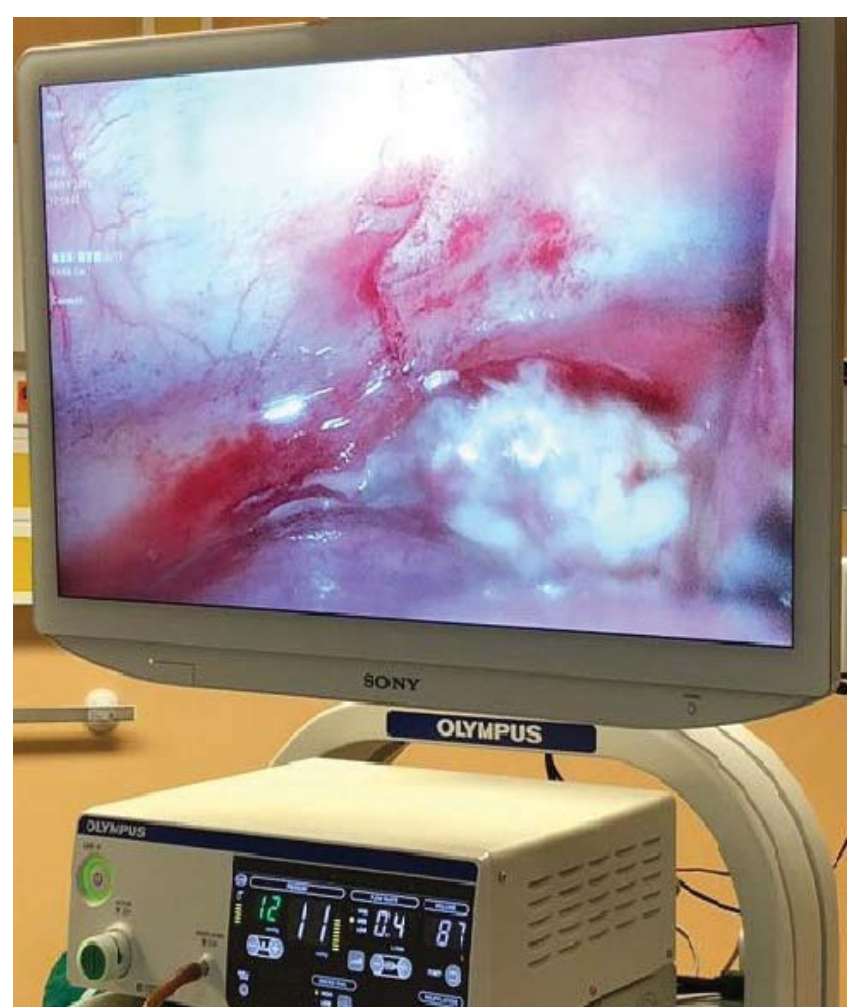

Figure 12. Thoracopscopy - mediastinal purulent collection evacuation.

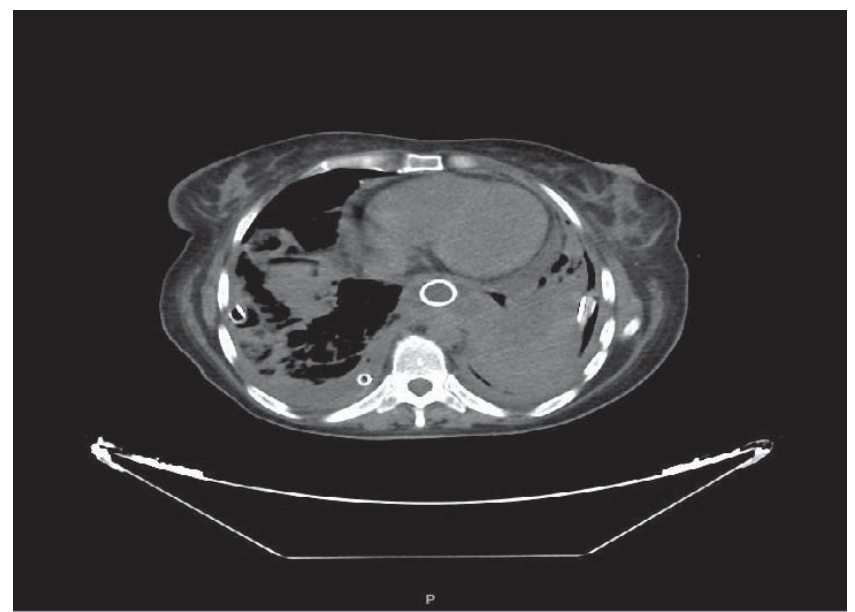

Figure 13. Computed tomography - bilateral pleural and medistinal drainages, oesophageal stent.

of intensive care, a computed tomography for control was required. It revealed the favourable evolution of lung parenchyma lesions, bilateral bronchopneumonia, interlobular septal thickening, right pleural effusion, the persistence of pericarditis, the oesophageal stent in normal position, the appearance of a paraoesophageal collection of $2.5 / 2 \mathrm{~cm}$, two mediastinal collections of

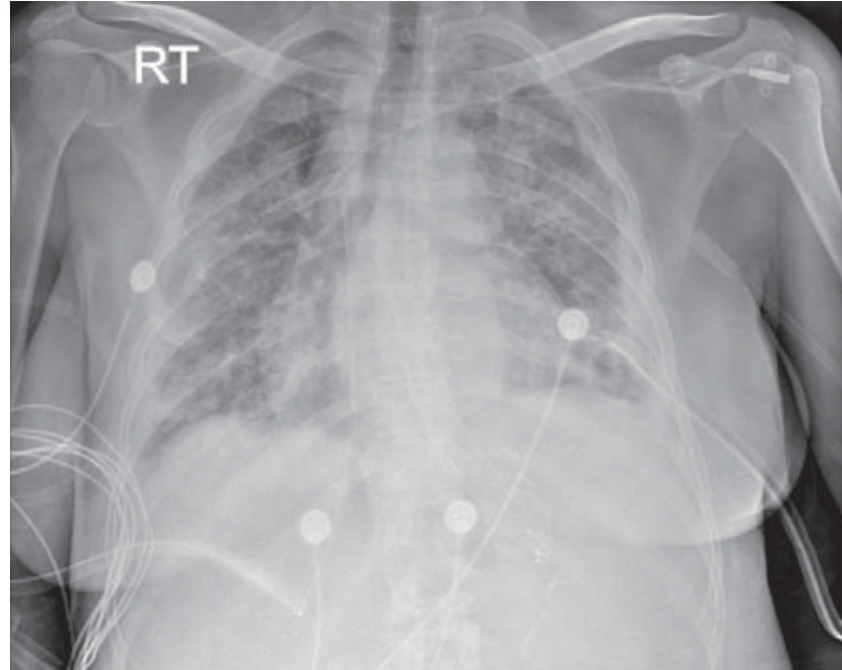

Figure 14. Chest X-ray - left pleural and right medistinal drainages.

$2.7 / 1.9 \mathrm{~cm}$ and $2.6 / 2 \mathrm{~cm}$ and a small transdiaphragmatic collection (Figure 10 and Figure 11). The patient underwent surgical intervention for evacuation of the mediastinal collections and a drainage tube was inserted into the mediastinum and in the right pleura ( $\mathrm{Fi}^{-}$ gure 12). Postoperative evolution was favourable, with daily reduction of the amount of pleural fluid and mediastinal drainages. However, complications appeared. There has been a decompensation of the neurological status due to her chronic anxiety-depressive disorder and, in a moment of psychomotor agitation, the patient accidentally has suppressed the mediastinal drainage tube. Therefore, in the $14^{\text {th }}$ day of intensive care, she underwent a new surgical intervention and a thoracoscopy was performed in order to evacuate the mediastinal collection and to reposition the drainage (Figure 13). After that, the clinical and paraclinical evolution were on an upward slope. Under specific medication, the neurological status has improved, the pleural and mediastinal drains were progressively reduced and the patient did not need high-flow oxygen therapy anymore, so the right pleural drainage was removed. She started to eat on her own with episodes of vomiting at first. In the $20^{\text {th }}$ day of intensive care, a new computed tomography examination was performed. The findings were promising, with favourable evolution of bronchopneumonia, fine bilateral pleural effusion, reduced dimensions of mediastinal and paraesophageal collections, normally positioned oesophageal stent and without increased size of pericardial fluid (Figure 14). Therefore, after 22 days in ICU, the patient was discharged to surgical ward for further treatment. 


\section{DISCUSSION}

Bariatric surgery, especially sleeve gastrectomy, may lead to rare but extremely severe pulmonary complications ${ }^{9}$. Early complications, like atelectasis or pulmonary embolism, are more common ${ }^{10}$. Late complications, as in the case presented, including gastro-bronchial or gastro-pleural fistulas, are described after sleeve gastrectomy ${ }^{2,3}$. Oesophageal-pleural fistula implies the existence of a pathological communication between oesophagus and pleural cavity, and it usually leads to life-threatening complications ${ }^{9}$. The exact mechanism for these fistulae's appearance is not clear, but it is believed to be related with some postoperative leaks, which lead to local abscesses formation and creation of a pathological tract between oesophagus/stomach and pleural cavity or a bronchus 9 .

Clinical findings in these cases are insidious, consisting mainly in chronic respiratory symptoms like cough, chest pain, wheezing and shortness of breath ${ }^{11}$. In these cases, patients are usually treated for a lung infection, until more diagnostic tests are performed and, therefore, the diagnosis is delayed, in some case, for several months ${ }^{11}$. In our patient, acute hypoxemic respiratory failure was severe, with dyspnoea, chest pain and tiredness. A chest X-ray was performed, finding a massive pleural effusion that required immediate drainage, with no secondary improvement of the respiratory status. Because of that, a computed tomography was required, that found the lack of substance in the anterior oesophageal wall and extravasation of oesophageal content in the posterior mediastinum, secondary to an oesophageal pleural fistula.

For this type of cases, minim-invasive surgical intervention techniques are usually required to evacuate the abscesses, associated with endoscopic repair using expandable stents ${ }^{2}$. There are a few reported cases in whom an endoscopic closure using human fibrin and endoscopic clip was performed ${ }^{12}$. However, most of these patients were in need for further surgical intervention because, after few months, the conservative management was not enough for fistula closure, and the symptoms reappeared ${ }^{9}$. For our patient, a fully covered self-expandable metal stent was placed, under endoscopic guidance, to cover the oesophageal mucosal defect. In addition, she underwent two surgical interventions for mediastinal and pleural collections drainage. Our patient should be periodically investigated to monitor the local evolution of the fistula and oesophagus, until full closure is obtained, or, in worst-case scenario, it should be surgically closed.

\section{CONCLUSION}

The appearance of an oesophageal-pleural fistula, years after sleeve gastrectomy, is a rare but extremely severe complication. It is a life-threatening condition, with non-specific manifestations and should be taken into account in patients with history of sleeve gastrectomy, as early or late complication. Early diagnosis and management is required. In some cases, a false-negative result can be obtained at first diagnostic imaging, but if there is a high index of suspicion, endoscopy or gastrography can be useful. Whenever is possible, endoscopic or minim-invasive surgical techniques should be firstly performed, complex surgical repair being the last resort.

Compliance with ethics requirements: The authors declare no conflict of interest regarding this article. The authors declare that all the procedures and experiments of this study respect the ethical standards in the Helsinki Declaration of 1975, as revised in 2008(5), as well as the national law. Informed consent was obtained from all the patients included in the study.

\section{References}

1. Futier E, Constantin JM, Paugam-Burtz C, Pascal J, Eurin M, Neuschwander A, Marret E, Beaussier M, Gutton C, Lefrant JY, Allaouchiche B. A trial of intraoperative low-tidal-volume ventilation in abdominal surgery. New England Journal of Medicine. 2013;369(5):428-37.

2. Garcia-Quintero P, Hernandez-Murcia C, Romero R, Derosimo J, Gonzalez A. Gastropleural fistula after bariatric surgery: a report of two cases. Journal of robotic surgery. 2015;9(2):163-6.

3. Sakran N, Assalia A, Keidar A, Goitein D. Gastrobronchial fistula as a complication of bariatric surgery: a series of 6 cases. Obesity facts. 2012;5(4):538-45.

4. Vyas S, Prakash M, Kaman L, Bhardwaj N, Khandelwal N. Spontaneous esophageal-pleural fistula. Lung India: official organ of Indian Chest Society. 2011;28(4):300.

5. Kumar, S., Singh, A., Matreja, P.S. and Kler, S.K., 2013. A case report of a spontaneous oesophageal pleural fistula. Journal of clinical and diagnostic research: JCDR, 7(3), p.522.

6. Lian R, Zhang G, Zhang G. Empyema caused by a colopleural fistula: A case report. Medicine. 2017;96(39).

7. Ghanem OM, Dayyeh BK, Kellogg TA. Management of gastropleural fistula after revisional bariatric surgery: a hybrid laparoendoscopic approach. Obesity surgery. 2017;27(10):2773-7. 
8. Debourdeau A, Gonzalez JM, Dutau H, Benezech A, Barthet M. Endoscopic treatment of nonmalignant tracheoesophageal and bronchoesophageal fistula: results and prognostic factors for its success. Surgical endoscopy. 2018;1-8.

9. Al-shurafa H, Alghamdi S, Albenmousa A, Alolayan H, Al-Shurafa Z. Gastropleural fistula after single anastomosis gastric bypass. A case report and review of the literature. International journal of surgery case reports. 2017;35:82-6.
10. Morino M, Toppino M, Forestieri P, Angrisani L, Allaix ME, Scopinaro N. Mortality after bariatric surgery: analysis of 13,871 morbidly obese patients from a national registry. Annals of surgery. 2007;246(6):1002-9.

11. Nguyen D, Dip F, Hendricks L, Menzo EL, Szomstein S, Rosenthal $R$. The surgical management of complex fistulas after sleeve gastrectomy. Obesity surgery. 2016;26(2):245-50.

12. Ladd AM, Al-Bayati I, Shah P, Haber G. Endoscopic closure of a gastropleural fistula. Endoscopy. 2015;47(S 01):E131-2. 
